\title{
Quantification of Colibactin-associated Genotoxicity in HeLa Cells by In Cell Western (ICW) Using $\boldsymbol{Y}$-H2AX as a Marker
}

Sophie Tronnet ${ }^{1, *}$ and Eric Oswald ${ }^{1,2,3}$

${ }^{1}$ IRSD, Université de Toulouse, INSERM, INRA, ENVT, UPS, Toulouse, France; ${ }^{2}$ Université Toulouse III Paul Sabatier, Toulouse, France; ${ }^{3} \mathrm{CHU}$ Toulouse, Service de Bactériologie-Hygiène, Toulouse, France *For correspondence: $\underline{\text { s.tronnet@gmail.com }}$

\begin{abstract}
[Abstract] The genotoxin colibactin is produced by several species of Enterobacteriaceae. This genotoxin induces DNA damage, cell cycle arrest, senescence and death in eukaryotic cells (Nougayrède et al., 2006; Taieb et al., 2016). Here we describe a method to quantify the genotoxicity of bacteria producing colibactin following a short infection of cultured mammalian cells with colibactin producing E. coli.
\end{abstract}

Keywords: Colibactin, Infection, Escherichia coli, Genotoxin, DNA damage, $y-\mathrm{H} 2 \mathrm{AX}$

[Background] The genotoxin colibactin is a polyketide nonribosomal peptide hybrid compound produced by several species of Enterobacteriaceae. This toxin, synthesized by a machinery encoded on a $54 \mathrm{~kb}$ genomic locus, the pks island, induces DNA damages, cell cycle arrest, senescence and death in eukaryotic cells (Nougayrède et al., 2006; Taieb et al., 2016). The genotoxic activity of colibactin is dependent on a direct host cell-bacteria interaction and cannot be recapitulated from culture supernatant, killed bacteria, or bacterial lysates instead of life bacteria. Visualization and quantification of the colibactin genotoxic effect on eukaryotic cells can be assessed by quantification of the megalocytosis phenotype (for a protocol see Bossuet-Greif et al., 2017) or quantification of the doublestrand DNA breaks in the host cell nucleus by a comet assay (revealing DNA fragmentation) or phosphorylation of the H2AX histone, a marker of double-strand DNA breaks. The phosphorylation of the histone $\mathrm{H} 2 \mathrm{AX}$ is characterized as an early and sensitive reaction to genotoxic agents (Audebert et al., 2010). H2AX phosphorylation was demonstrated to be 10-100 times more sensitive than the comet assay in vitro as well as in vivo (Audebert et al., 2010). The quantification of phosphorylated histone $\mathrm{H} 2 \mathrm{AX}(y-\mathrm{H} 2 \mathrm{AX})$ can be processed by the In-Cell Western Assay, an immunochemical assay that uses fluorescence to detect and quantify proteins in fixed cells (Audebert et al., 2010). Here we describe an adapted assay allowing the measurement of $\gamma$-H2AX in 96-well plate using In-Cell Western, following a short infection of cultured mammalian cells with colibactin-producing bacteria (Martin et al., 2013; Bossuet-Greif et al., 2016; Tronnet et al., 2017). 


\section{Materials and Reagents}

1. Black tissue culture plate 96 wells flat bottom (Greiner Bio One International, catalog number: 655090)

2. Parafilm

3. Aluminum foil

4. $\mathrm{pks}^{+}$and pks- Escherichia coli strains (stored in LB $20 \%$ glycerol at $-80^{\circ} \mathrm{C}$ )

Note: Strains typically used as positive controls in the authors' laboratory are probiotic strain Nissle 1917 or the commensal strain M1/5. Strains used as a negative control are the K-12 strain MG1655. Our lab can provide these strains.

5. HeLa cells (ATCC, catalog number: CCL-2), 20 passages maximum

6. Lennox L broth base (LB medium; Thermo Fisher Scientific, Invitrogen ${ }^{\mathrm{TM}}$, catalog number: 12780029)

7. Dulbecco's modified Eagle medium (DMEM) with 25 mM HEPES (Thermo Fisher Scientific, Gibco $^{\mathrm{TM}}$, catalog number: 42430 )

8. Hanks' balanced salt solution (HBSS; Sigma-Aldrich, catalog number: H8264)

9. Gentamicin solution $50 \mathrm{mg} / \mathrm{ml}$ (Sigma-Aldrich, catalog number: G1397)

10. Dulbecco's phosphate buffered saline (PBS; Sigma-Aldrich, catalog number: D8537)

11. Dulbecco's modified Eagle medium (DMEM), high glucose, GlutaMax Supplement, pyruvate (Thermo Fisher Scientific, Gibco ${ }^{\mathrm{TM}}$, catalog number: 31966021)

12. Fetal bovine serum (FBS; Thermo Fisher Scientific, Gibco ${ }^{T M}$, catalog number: 10270106)

13. Non-essential amino acids solution (NEAA) 100x (Thermo Fisher Scientific, Gibco ${ }^{\mathrm{TM}}$, catalog number: 11140035)

14. Paraformaldehyde (PFA) 20\% (Electron Microscopy Sciences, catalog number: 15713)

15. 10x PBS (Sigma-Aldrich, catalog number: D1408)

16. Ammonium chloride $\left(\mathrm{NH}_{4} \mathrm{Cl}\right.$; BioUltra, Sigma-Aldrich, catalog number: 09718-250G)

17. Triton ${ }^{\mathrm{TM}} \mathrm{X}-100$ (Sigma-Aldrich, catalog number: $\mathrm{X} 100-500 \mathrm{ML}$ )

18. MAXblock blocking medium (Active Motif, catalog number: 15252)

19. Phosphatase inhibitor PHOSTOP (10x, Roche Diagnostics, catalog number: 04906837001)

20. RNase (Sigma-Aldrich, catalog number: R6513)

21. Sodium chloride ( $\mathrm{NaCl}$; Sigma-Aldrich, catalog number: $\mathrm{S} 7653$ )

22. Sodium azide (Sigma-Aldrich, catalog number: S8032)

23. Rabbit monoclonal anti- $\gamma-\mathrm{H} 2 \mathrm{AX}$ antibody (Cell Signaling Technology, catalog number: 9718 )

24. IRDye ${ }^{\mathrm{TM}} 800 \mathrm{CW}$-conjugated goat anti-rabbit secondary antibody $(2 \mathrm{mg} / \mathrm{ml}$, Biotium (distributor Interchim), catalog number: 20078)

25. RedDot ${ }^{\mathrm{TM}} 2$ (200x in DMSO, Biotium (distributor Interchim), catalog number: 40061)

26. HeLa cell culture medium (see Recipes)

27. Fixation solution (see Recipes)

28. Neutralization solution (see Recipes) 
29. $10 \%$ Triton $X-100$ (see Recipes)

30. Permeabilization solution (see Recipes)

31. Blocking solution (see Recipes)

32. Permeabilization solution (see Recipes)

33. PST buffer (see Recipes)

34. 100x azide (see Recipes)

35. Anti- $\gamma-\mathrm{H} 2 \mathrm{AX}$ solution (see Recipes)

36. Secondary antibody solution (see Recipes)

\section{Equipment}

1. $37^{\circ} \mathrm{C}, 5 \% \mathrm{CO}_{2}$ incubator for cell cultures

2. $37^{\circ} \mathrm{C}$ incubator for bacterial cultures

3. Microplate reader with 680 and $800 \mathrm{~nm}$ channels (here, Odyssey Infrared Imaging Scanner, LiCor ScienceTec, Les Ulis, France)

4. Microplate reader for absorbance measurement at $600 \mathrm{~nm}$ (TECAN Infinite Pro)

5. Colorimeter to measure the absorbance at $600 \mathrm{~nm}$ of bacterial cultures (Biochrom, model: WPA CO7500)

6. Variable Speed Rocker (VWR, catalog number: 75832-308)

7. Chemical safety hood

8. Clean bench

9. Inverted microscope (Olympus, model: CKX31)

10. Pipettes and multichannel micropipette $30-300 \mu \mathrm{l}$

\section{Software}

1. GraphPad Prism 6.0

\section{Procedure}

Day 1

1. Bacteria are cultured overnight in $3 \mathrm{ml}$ of LB from $-80{ }^{\circ} \mathrm{C}$ glycerol stock or a colony on an LB agar plate at $37^{\circ} \mathrm{C}$ with shaking $(220 \mathrm{rpm})$.

2. HeLa cells are dispensed in a black 96 -well tissue culture plate with transparent bottom $(1.5 \mathrm{x}$ $10^{4}$ cells/well) and grown for $24 \mathrm{~h}$ in $200 \mu \mathrm{l} \mathrm{HeLa} \mathrm{cell} \mathrm{culture} \mathrm{medium} \mathrm{(see} \mathrm{Recipes)} \mathrm{at} 37^{\circ} \mathrm{C}$ in a $\mathrm{CO}_{2}$ incubator.

Note: Importantly, don't dispense any cells in the two bottom-left wells (see Figure 1: plate infection scheme). 


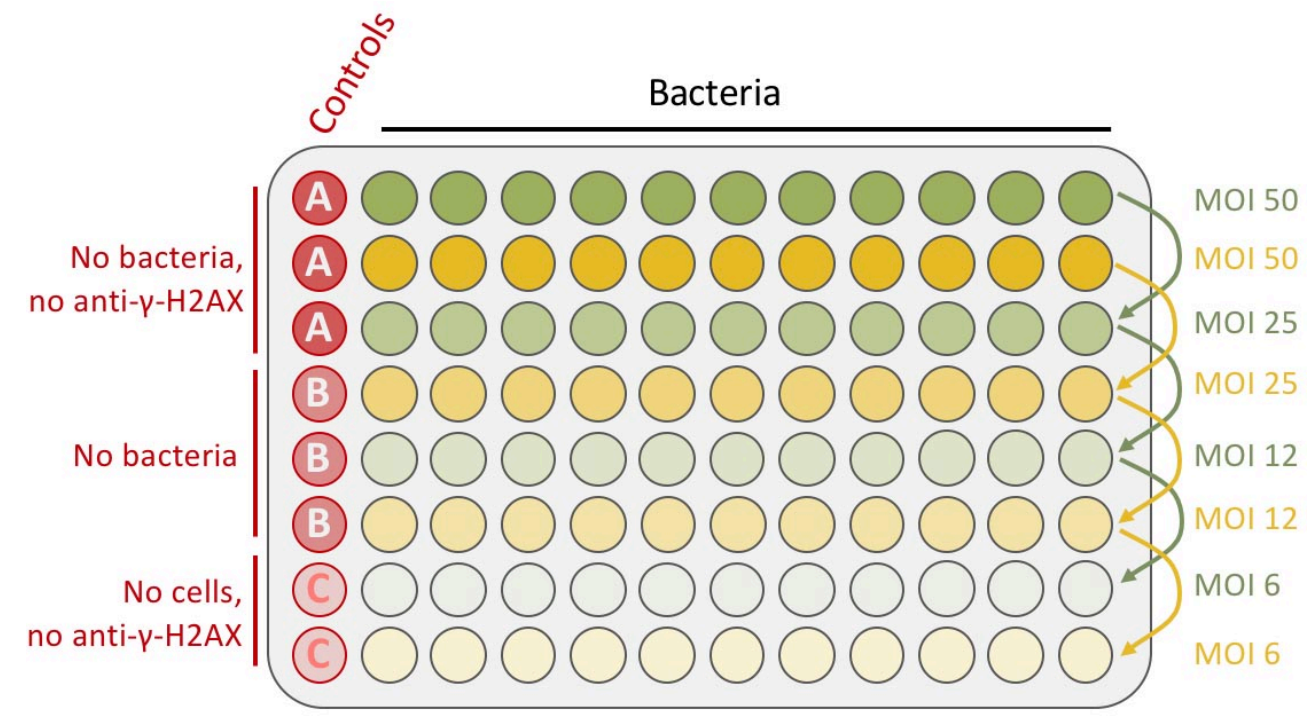

Figure 1. Schematic representation of plate infection example. Bacteria are inoculated in the two first rows in duplicate (in $200 \mu \mathrm{l} /$ well of DMEM-HEPES medium), at an MOI of 50 and then 2-fold serially diluted (by successively transferring $100 \mu \mathrm{l}$ to the rows below). The final volume is $100 \mu \mathrm{l}$. The left column is kept for the controls (red wells column).

Day 2

1. Bacterial preparation

Bacteria are sub-cultured by diluting $50 \mu \mathrm{l}$ of the overnight culture in $5 \mathrm{ml}$ of DMEM-HEPES medium (i.e., 1:100 dilution) and grown at $37^{\circ} \mathrm{C}$ with agitation $(220 \mathrm{rpm})$ until an average $\mathrm{OD}_{600 \mathrm{~nm}}=0.6$. The number of bacteria per $\mathrm{ml}$ is determined by measuring the $\mathrm{OD}_{600 \mathrm{~nm}}$ of $1 \mathrm{ml}$ of the culture.

Note: The typical value for $E$. coli is 1 unit of the $O D_{600 \mathrm{~nm}}$ corresponds to $5 \times 10^{8} \mathrm{bacteria} / \mathrm{ml}$.

2. HeLa cells preparation

a. Before infection, eukaryotic cells are cautiously washed once with pre-warmed $\left(37^{\circ} \mathrm{C}\right)$ HBSS.

b. $100 \mu \mathrm{l}$ of DMEM-HEPES medium is added in all the wells, except the 2 first rows, corresponding to the highest number of bacteria per cell (maximum multiplicity of infection or MOI) where $200 \mu \mathrm{l}$ of DMEM-HEPES medium is added (Figure 1).

3. Infection assay

a. After determination of the multiplicity of infection (MOI = number of bacteria per HeLa cell at the onset of the infection), the appropriate number of bacteria is added in the first 2 rows of the plate (containing $200 \mu$ L DMEM-HEPES medium).

b. 2-fold serial dilution is performed to create an infectious dose-effect, in a final DMEMHEPES medium volume of $100 \mu \mathrm{l}$ (Figure 1).

Note: As an example, for an MOI of 50, add $50 \times 1.5 \times 10^{4}=75 \times 10^{4}$ bacteria for a well containing $1.5 \times 10^{4} \mathrm{HeLa}$ cells. The number of dispensed cells is taken into account for the $\mathrm{MOI}$ calculation. 
c. The plate is incubated for $4 \mathrm{~h}$ in a cell culture incubator.

4. End of the infection and post-infection incubation

a. After infection of $4 \mathrm{~h}$, the absorbance at $600 \mathrm{~nm}$ is measured with a microplate reader, to monitor bacterial growth. The typical values obtained are around 0.2-0.3 for MOI 50 .

b. Then, cells are washed carefully at least 3 times with an increasing volume of pre-warm $\left(37^{\circ} \mathrm{C}\right) \mathrm{HBSS}(100 \mu \mathrm{l}, 150 \mu \mathrm{l}$ and finally $200 \mu \mathrm{l})$. The plate is observed under an inverted microscope to check whether most of the bacteria are removed. If required, additional washes can be performed.

c. Finally, cells are incubated in $200 \mu \mathrm{l}$ cell culture medium (see Recipes) for $3 \mathrm{~h}$ with 200 $\mathrm{mg} / \mathrm{ml}$ gentamicin in a cell culture incubator.

5. Cells fixation

a. The cells are washed carefully in cold PBS $(100 \mu \mathrm{l})$ three times.

b. $100 \mu$ fixation solution (see Recipes) is added for 20 min under a chemical safety hood.

6. Paraformaldehyde neutralization

a. After the fixation step, cells are washed with PBS ( $100 \mu \mathrm{l}$ per well), for 5 min under rapid agitation (variable speed shaker, 20-25 rpm). This washing step is repeated 3 times.

b. Then, the paraformaldehyde is neutralized by adding $50 \mu \mathrm{l}$ of neutralization solution (see Recipes) for 2 min under slow agitation (3-5 rpm).

7. Cells permeabilization

a. The cells are washed 3 times for 5 min with PBS, $100 \mu$ per well, under rapid agitation (20$25 \mathrm{rpm}$ ) as previously (Step 6).

b. Then cells are permeabilized with cold permeabilization solution (see Recipes), $50 \mu \mathrm{l}$ per well for $5 \mathrm{~min}$, under slow agitation.

8. Blocking step

a. Cells are washed 3 times with PST buffer (see Recipes), $100 \mu$ per well, under agitation (20-25 rpm).

b. Then, $50 \mu \mathrm{l} /$ well of blocking solution (see Recipes) is added, and the plate is incubated at room temperature for 60 min under agitation (3-5 rpm).

9. Anti- $y-\mathrm{H} 2 \mathrm{AX}$ immunostaining step

a. Before immunostaining, cells are washed with PST buffer 3 times, $100 \mu l$ for 5 min under agitation (20-25 rpm).

b. $25 \mu$ l per well of anti- $\gamma-\mathrm{H} 2 \mathrm{AX}$ solution (see Recipes) is added and the plate is incubated for $2 \mathrm{~h}$ at room temperature or overnight at $4{ }^{\circ} \mathrm{C}$ (in that case, the plate has to be sealed carefully with Parafilm to avoid drying), under agitation (3-5 rpm).

Note: This solution is not added in the controls $A$ and C (Figure 1), $25 \mu$ of PST buffer is added instead during the incubation time.

10. Secondary detection step

a. Cells are first washed 3 times with PST buffer, $100 \mu \mathrm{l}$ per well for 5 min under agitation (20$25 \mathrm{rpm})$. 
b. Secondary detection is carried out using an infrared fluorescent dye conjugated IRDye ${ }^{\mathrm{TM}}$ $800 \mathrm{CW}$-conjugated goat anti-rabbit antibodies absorbing at $800 \mathrm{~nm}(1 / 1,000)$ in PST buffer. For DNA labeling, 1/1,000 dilution of RedDot ${ }^{\mathrm{TM}} 2$ in PST is used together with the secondary antibody (see secondary antibody solution in Recipes), $25 \mu \mathrm{l}$ per well in every well of the plate.

c. The plate is incubated in the dark for $1 \mathrm{~h}$ under agitation (3-5 rpm).

11. Plate scanning step

a. The plate is washed 3 times in PST buffer, $100 \mu$ per well for 5 min under agitation (20-25 $\mathrm{rpm}$ ) in obscurity (covered with aluminum foil).

b. Then, the plate is dried by reversing and patting it delicately on a tissue.

c. The DNA and the $y-\mathrm{H} 2 \mathrm{AX}$ were simultaneously visualized using an Odyssey Infrared Imaging Scanner with the $680 \mathrm{~nm}$ fluorophore (red color) and the $800 \mathrm{~nm}$ fluorophore (green dye), respectively (Figure 3A).

Note: Once the plate dried (Step 11b), it can be conserved several months, at $4{ }^{\circ} \mathrm{C}$ protected from the light, upside down, before visualization.

\section{Data analysis}

A quantitative analysis of the frequency of DNA double-strand breaks can be performed using the fluorescence values (in RFU) obtained from the scans (Figures 2 and 3B). Firstly, the average $\gamma$ $\mathrm{H} 2 \mathrm{AX}$ fluorescence per cell is obtained by dividing the measured $y-\mathrm{H} 2 \mathrm{AX}$ fluorescence per well (at $800 \mathrm{~nm}$ ) by the corresponding measured fluorescence for RedDot-labelled DNA per well (at $680 \mathrm{~nm}$ ) (Figure 2). The value for $y-\mathrm{H} 2 \mathrm{AX}$ fluorescence per cell is divided by the average fluorescence value at $800 \mathrm{~nm}$ obtained for the two wells serving as vehicle control (here corresponding to the wells marked ' $C$ ' in Figures 1 and 2) to determine the percent change in phosphorylation of H2AX levels relative to the vehicle control. The obtained number is defined as a genotoxic index (or $\gamma$-H2AX fold induction) and typically ranges from 0 to 2 in completely healthy cells, to 5 to 7 in cells infected with colibactin-producing E. coli at MOI 25 (Figure 2 and Figure 3B). 


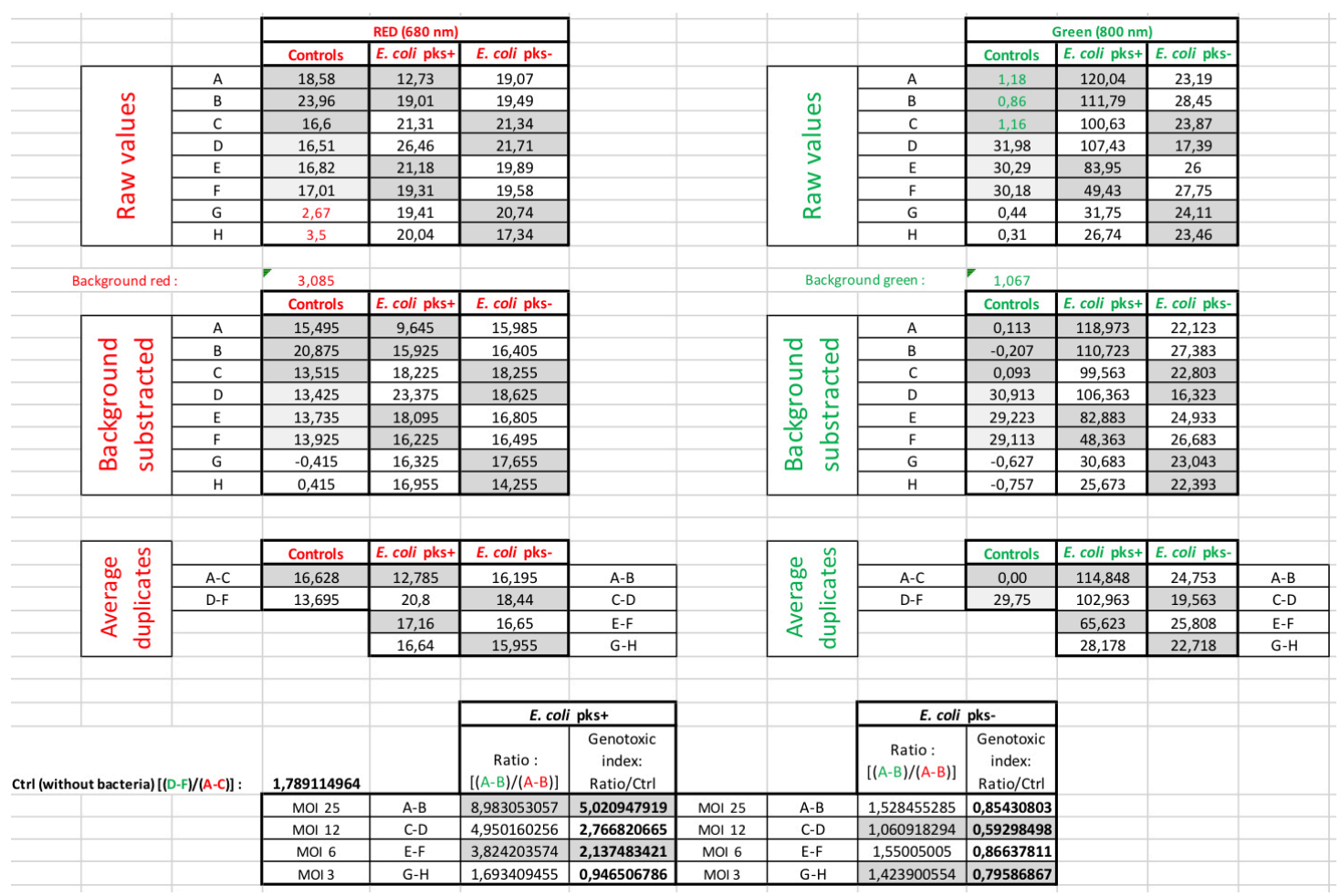

Figure 2. Data analysis of $\boldsymbol{y}-\mathrm{H} 2 \mathrm{AX}$ quantification. Representative image of how we process data from the raw numbers to the calculation of the $y-\mathrm{H} 2 \mathrm{AX}$ fold induction (genotoxic index).

A.

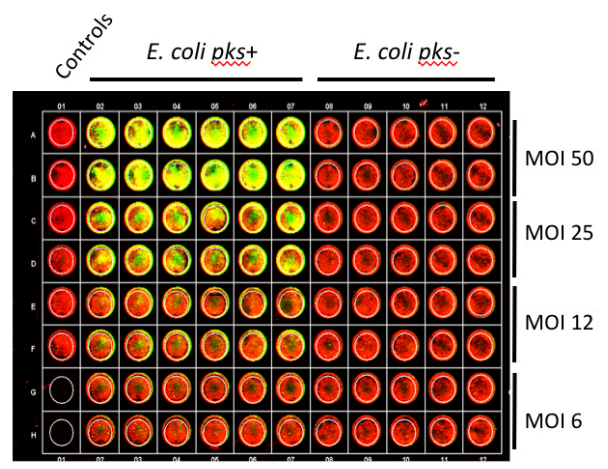

B.

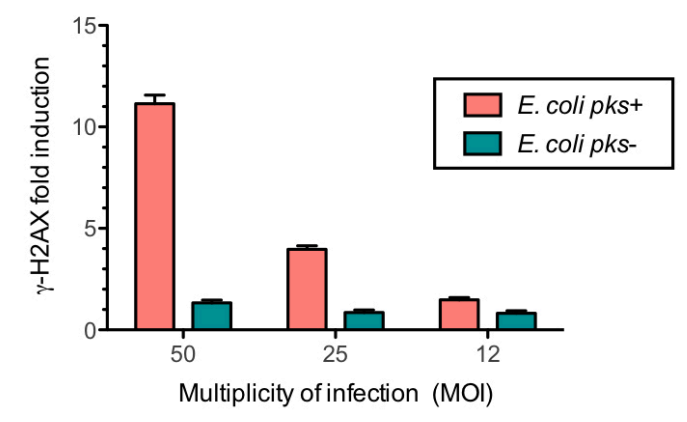

Figure 3. Quantification of phosphorylated H2AX ( $y-\mathrm{H} 2 \mathrm{AX})$ from infected HeLa cells with pks $^{+}$E. coli or with pks ${ }^{-}$. coli at various MOI. A. Example of an In-Cell Western plate image with merged detection of total DNA (red, $680 \mathrm{~nm}$ ) and $y$-H2AX (green, $800 \mathrm{~nm}$ ). A high level of $\gamma-\mathrm{H} 2 \mathrm{AX}$ can be observed at high $\mathrm{MOI}$ for the cells infected with E. coli pks ${ }^{+}$. B. The $\gamma-\mathrm{H} 2 \mathrm{AX}$ fold induction ( $y-\mathrm{H} 2 \mathrm{AX}$ fluorescence normalized to the amount of cells per well), calculated relative to the control (non-infected cells), reveals a genotoxic dose-response depending on the $\mathrm{MOI}$ in cells infected by colibactin-producing bacteria $\left(E\right.$. coli $\left.p k s^{+}\right)$compared to cells infected by non colibactin-producing bacteria (E. coli $\left.p k s^{-}\right)$. Data represented in the graph were obtained from two biological replicates and two independent experiments. Data were plotted using GraphPad Prism 6.0. The mean with standard deviation (sd) is shown. 


\section{Recipes}

1. HeLa cells culture medium

$450 \mathrm{ml}$ DMEM high glucose with pyruvate and GlutaMax

$50 \mathrm{ml}$ fetal bovine serum

$5 \mathrm{ml}$ NEAA

2. Fixation solution (1x PBS, 4\% PFA)

$5 \mathrm{ml}$ PFA stock solution

$5 \mathrm{ml} \mathrm{20 \% 10x} \mathrm{PBS}$

$40 \mathrm{ml}$ distilled water

Aliquot and store at $-20^{\circ} \mathrm{C}$

Defreeze one aliquot the day of the experiment

3. Neutralization solution ( $20 \mathrm{mM} \mathrm{NH}_{4} \mathrm{Cl}$ in PBS)

a. Prepare the stock solution $\left(1 \mathrm{M} \mathrm{NH}_{4} \mathrm{Cl}\right)$ in distilled water and store at $4{ }^{\circ} \mathrm{C}$

b. Dissolve the stock solution in PBS to reach the appropriate concentration

c. Keep on ice until use

4. $10 \%$ Triton $\mathrm{X}-100$

$500 \mu \mathrm{l}$ Triton $\mathrm{X}-100$ in $50 \mathrm{ml}$ PBS

This solution can be stored at $4{ }^{\circ} \mathrm{C}$ for 2-3 weeks

5. Permeabilization solution (1x PBS, $0.2 \%$ Triton $X-100$ )

$200 \mu \mathrm{l} 10 \%$ Triton X-100

$10 \mathrm{ml}$ PBS

Keep on ice until use

6. Blocking solution (MAXblock blocking medium, 1x PHOSTOP inhibitor, RNase [100 $\mu \mathrm{g} / \mathrm{ml}]$ )

4.5 ml MAXblock blocking medium

500 ul 10x PHOSTOP inhibitor

$50 \mu \mathrm{l}$ RNase stock solution (10 mg/ml in PBS, $10 \mathrm{mM}$ HEPES pH 7.5, $15 \mu \mathrm{M} \mathrm{NaCl}$, aliquot stored at $-20^{\circ} \mathrm{C}$ )

Keep on ice until use

7. PST buffer (PBS, $2 \%$ fetal calf serum, $0.2 \%$ Triton $\mathrm{X}-100$ )

$48 \mathrm{ml}$ PBS

$1 \mathrm{ml} 2 \%$ fetal calf serum

$1 \mathrm{ml} 0.2 \%$ Triton X-100 in PBS

8. $100 x$ azide

Dissolve sodium azide in distilled water at a final concentration of $50 \mathrm{mg} / \mathrm{ml}(5 \% \mathrm{w} / \mathrm{w})$, store at $4{ }^{\circ} \mathrm{C}$

9. Anti- $\gamma-\mathrm{H} 2 \mathrm{AX}$ solution (rabbit monoclonal anti- $\gamma-\mathrm{H} 2 \mathrm{AX}[1 / 200]$ in PST buffer, $500 \mu \mathrm{g} / \mathrm{ml}$ azide) $1.5 \mathrm{ml}$ PST buffer

$7.5 \mu \mathrm{l}$ anti- $\gamma-\mathrm{H} 2 \mathrm{AX}$ 
$15 \mu \mathrm{l} 100 \mathrm{x}$ azide

Note: This solution can be reused 2-3 times, and stored at $5{ }^{\circ} \mathrm{C}$ for several weeks.

10. Secondary antibody solution (IRDye ${ }^{\mathrm{TM}} 800 \mathrm{CW}$ Goat Anti-Rabbit $[1 / 1,000]$, RedDot ${ }^{\mathrm{TM}} 2[1 / 1,000]$ in PST buffer)

$2.5 \mathrm{ml} \mathrm{PST}$

$2.5 \mu \mathrm{IIRDye}{ }^{\mathrm{TM}} 800 \mathrm{CW}$ Goat Anti-Rabbit

$2.5 \mu \mathrm{l} \operatorname{RedDot}^{\mathrm{TM}} 2$

\section{Acknowledgments}

This protocol was adapted from previously published work (Audebert et al., 2010; Martin et al., 2013; Bossuet-Greif et al., 2016; Tronnet et al., 2017). This work was supported by the Agence Nationale de la Recherche (France) [grant ANR-13-BSV3-0015-02, ANR-13-BSV1-0028-01]. The authors declare no conflicts of interest or competing interests, regarding the publication of this protocol.

\section{References}

1. Audebert, M. Riu, A., Jacques, C., Hillenweck, A., Jamin, E. L., Zalko, D., Cravedi, J. P. (2010). Use of the gammaH2AX assay for assessing the genotoxicity of polycyclic aromatic hydrocarbons in human cell lines. Toxicol Lett 199: 182-192.

2. Bossuet-Greif, N., Belloy, M., Boury, M., Oswald, E. and Nougayrede, J. (2017). Protocol for HeLa cells infection with Escherichia coli strains producing colibactin and quantification of the induced DNA-damage. Bio-protocol 7(16): e2520.

3. Bossuet-Greif, N., Dubois, D., Petit, C., Tronnet, S., Martin, P., Bonnet, R., Oswald, E. and Nougayrede, J. P. (2016). Escherichia coli ClbS is a colibactin resistance protein. Mol Microbiol 99(5): 897-908.

4. Martin, P., Marcq, I., Magistro, G., Penary, M., Garcie, C., Payros, D., Boury, M., Olier, M., Nougayrede, J. P., Audebert, M., Chalut, C., Schubert, S. and Oswald, E. (2013). Interplay between siderophores and colibactin genotoxin biosynthetic pathways in Escherichia coli. PLoS Pathog 9(7): e1003437.

5. Nougayrède, J. P., Homburg, S., Taieb, F., Boury, M., Brzuszkiewicz, E., Gottschalk, G., Buchrieser, C., Hacker, J., Dobrindt, U. and Oswald, E. (2006). Escherichia coli induces DNA double-strand breaks in eukaryotic cells. Science 313(5788): 848-851.

6. Taieb, F., Petit, C., Nougayrede, J. P. and Oswald, E. (2016). The enterobacterial genotoxins: cytolethal distending toxin and colibactin. EcoSal Plus 7(1).

7. Tronnet, S., Garcie, C., Brachmann, A. O., Piel, J., Oswald, E. and Martin, P. (2017). High iron supply inhibits the synthesis of the genotoxin colibactin by pathogenic Escherichia coli through a non-canonical Fur/RyhB-mediated pathway. Pathog Dis 75(5). 